\title{
AMP-activated protein kinase (AMPK) $\alpha 2$ plays a role in determining the cellular fate of glucose in insulin-resistant mouse skeletal muscle
}

\author{
R. S. Lee-Young • J. S. Bonner • W. H. Mayes • \\ I. Iwueke • B. A. Barrick • C. M. Hasenour • L. Kang • \\ D. H. Wasserman
}

Received: 3 May 2012 / Accepted: 1 November 2012 /Published online: 8 December 2012

(C) Springer-Verlag Berlin Heidelberg 2012

\begin{abstract}
Aims/hypothesis We determined whether: (1) an acute lipid infusion impairs skeletal muscle AMP-activated protein kinase (AMPK) $\alpha 2$ activity, increases inducible nitric oxide synthase (iNOS) and causes peripheral insulin resistance in conscious, unstressed, lean mice; and (2) restoration of AMPK $\alpha 2$ activity during the lipid infusion attenuates the increase in iNOS and reverses the defect in insulin sensitivity in vivo.

Methods Chow-fed, 18-week-old C57BL/6J male mice were surgically catheterised. After 5 days they received: (1) a $5 \mathrm{~h}$ infusion of $5 \mathrm{ml} \mathrm{kg}^{-1} \mathrm{~h}^{-1}$ Intralipid $+6 \mathrm{U} / \mathrm{h}$ heparin (Lipid treatment) or saline (Control); (2) Lipid treatment or Control, followed by a $2 \mathrm{~h}$ hyperinsulinaemic-euglycaemic clamp (insulin clamp; $4 \mathrm{mU} \mathrm{kg} \mathrm{min}^{-1}$ ); and (3) infusion of the AMPK activator, 5-aminoimidazole-4-carboxamide 1 - $\beta$-D-ribofuranoside (AICAR) $\left(1 \mathrm{mg} \mathrm{kg}^{-1} \mathrm{~min}^{-1}\right)$, or saline during Lipid treatment, followed by a $2 \mathrm{~h}$ insulin clamp. In a separate protocol, mice producing a muscle-specific kinasedead AMPK $\alpha 2$ subunit $(\alpha 2-\mathrm{KD})$ underwent an insulin clamp to determine the role of AMPK $\alpha 2$ in insulinmediated muscle glucose metabolism.
\end{abstract}

R. S. Lee-Young $(\bowtie)$

Cellular and Molecular Metabolism Laboratory,

Division of Metabolism and Obesity,

Baker IDI Heart and Diabetes Institute, 75 Commercial Rd,

Melbourne, VIC 3004, Australia

e-mail: robert.lee-young@bakeridi.edu.au

R. S. Lee-Young · J. S. Bonner • W. H. Mayes · I. Iwueke •

B. A. Barrick · C. M. Hasenour ' L. Kang - D. H. Wasserman

Department of Molecular Physiology and Biophysics,

Vanderbilt University School of Medicine, Nashville, TN, USA

R. S. Lee-Young • D. H. Wasserman

Mouse Metabolic Phenotyping Center,

Vanderbilt University School of Medicine, Nashville, TN, USA
Results Lipid treatment decreased AMPK $\alpha 2$ activity, increased iNOS abundance/activation and reduced whole-body insulin sensitivity in vivo. AICAR increased AMPK $\alpha 2$ activity twofold; this did not suppress iNOS or improve whole-body or tissuespecific rates of glucose uptake during Lipid treatment. AICAR caused a marked increase in insulin-mediated glycogen synthesis in skeletal muscle. Consistent with this latter result, lean $\alpha 2-\mathrm{KD}$ mice exhibited impaired insulin-stimulated glycogen synthesis even though muscle glucose uptake was not affected.

Conclusions/interpretation Acute induction of insulin resistance via lipid infusion in healthy mice impairs AMPK $\alpha 2$, increases iNOS and causes insulin resistance in vivo. However, these changes do not appear to be interrelated. Rather, a functionally active AMPK $\alpha 2$ subunit is required for insulin-stimulated muscle glycogen synthesis.

Keywords AICAR · Glucose metabolism · Glycogen synthesis $\cdot$ Skeletal muscle

$\begin{array}{ll}\begin{array}{l}\text { Abbreviations } \\ \alpha 2-\mathrm{KD}\end{array} & \text { Kinase-dead AMPK } \alpha 2 \text { subunit } \\ \text { ACC } & \text { Acetyl-CoA carboxylase } \\ \text { AICAR } & \begin{array}{l}\text { 5-Aminoimidazole-4-carboxamide 1- } \beta \text {-D- } \\ \text { ribofuranoside }\end{array} \\ \text { AMPK } & \text { AMP-activated protein kinase } \\ 2-\left[{ }^{14} \mathrm{C}\right] \mathrm{DG} & \text { 2-Deoxy }\left[{ }^{14} \mathrm{C}\right] \text { glucose } \\ \text { Endo } R_{\mathrm{a}} & \text { Endogenous rates of glucose appearance } \\ \text { GAPDH } & \text { Glyceraldehyde 3-phosphate dehydrogenase } \\ \text { GIR } & \text { Glucose infusion rate } \\ \text { GS } & \text { Glycogen synthase } \\ \text { iNOS } & \text { Inducible nitric oxide synthase } \\ R_{\mathrm{a}} & \text { Rates of glucose appearance } \\ R_{\mathrm{d}} & \text { Rates of glucose disappearance } \\ R_{\mathrm{g}} & \text { Tissue-specific indices of muscle glucose uptake } \\ \mathrm{ZMP} & \text { 5-Amino-4-imidazolecarboxamide ribotide }\end{array}$




\section{Introduction}

Skeletal muscle is the largest organ in the human body and the primary site of insulin-stimulated glucose uptake and metabolism [1]. Any impairment in these processes plays an integral role in the development of metabolic disease states, notably obesity and type 2 diabetes. A major therapeutic option for obesity and type 2 diabetes are the biguanide or thiazolidinedione classes of glucoselowering drugs, which enhance rates of skeletal muscle glucose uptake and storage [2]. While the exact signalling mechanism(s) responsible for this phenomenon is (are) unclear, a common mechanistic link involves the activation of AMP-activated protein kinase (AMPK), a serine-threonine $\alpha \beta \gamma$ heterotrimer thought to act as a regulator of skeletal muscle glucose fluxes [3]. Indeed, the metal binding properties of biguanides appear to regulate the activation of AMPK [4].

Pharmacological activation of AMPK $\alpha 2$ is associated with improved insulin sensitivity [5-7]. The mechanism(s) by which AMPK $\alpha 2$ mediates this process is(are) unclear, although one possible mechanism relates to suppression of inducible nitric oxide synthase (iNOS). iNOS, an isozyme of the nitric oxide synthase family, plays a role in a number of biological processes, including pathological conditions such as insulin resistance. In skeletal muscle, iNOS abundance is enhanced in obesity and type 2 diabetes $[8,9]$. Deletion of iNOS improves insulin sensitivity $[8,10]$ and intracellular insulin signalling [11] in animal models of insulin resistance. In cell cultures, reduced AMPK $\alpha$ activation is associated with enhanced iNOS production [12], whereas pharmacological activation of AMPK $\alpha$ reduces iNOS levels $[12,13]$. Obesity and insulin resistance are associated with impaired skeletal muscle AMPK $\alpha 2$ activation $[6,14,15]$, although not all studies have observed this $[16,17]$. Nevertheless, it is possible that the impaired skeletal muscle AMPK $\alpha 2$ activation seen in obesity and type 2 diabetes contributes to the elevated iNOS levels seen in these metabolic disease states. Due to the many complexities involved in obesity and type 2 diabetes, the association between AMPK $\alpha 2$ and iNOS is difficult to pinpoint.

The aim of this study was to elucidate the role of skeletal muscle AMPK $\alpha 2$ in insulin resistance, without the associated complications of chronic obesity. Specifically, we tested the hypothesis that: (1) an acute lipid emulsion infusion that results in insulin resistance would impair skeletal muscle AMPK $\alpha 2$ activity in vivo in lean healthy mice; (2) impaired AMPK $\alpha 2$ activity would lead to enhanced levels of iNOS in skeletal muscle; and (3) the restoration of AMPK $\alpha 2$ activity during the lipid infusion (via infusion of the AMPK activator AICAR) would reverse the defect in insulin sensitivity in vivo by suppressing iNOS.

\section{Methods}

Animal maintenance The principles of laboratory animal care were followed. Procedures were approved by the Vanderbilt University Animal Care and Use Committee. Male, 18-weekold C57BL/6J mice (Jackson Laboratories, Bar Harbor, ME, USA) and 16-week-old C57BL/6 mice expressing a musclespecific kinase-dead Ampka2 (also known as Prkaa2) subunit $(\alpha 2-K D)[18]$ were used. All mice were fed a standard chow diet (5001 Laboratory Rodent Diet; Purina, Richmond, IN, USA) with free access to water.

Surgical procedures At 5 days prior to the experiment, mice underwent surgery to catheterise the left common carotid artery and right jugular vein as described previously [19], with the modification that mice were anaesthetised with isofluorane. Mice were housed individually after surgery and were within $10 \%$ of the pre-surgery weight on the day of study.

Intralipid infusion and hyperinsulinaemic-euglycaemic clamp protocols Between 07:00 and 08:00 hours mice were placed into new cages containing bedding, but no food and water, and underwent one of four protocols (Fig. 1) as follows.

Protocol 1: lipid emulsion (Lipid treatment; $5 \mathrm{ml} \mathrm{kg}^{-1}$ $\mathrm{h}^{-1}$ Intralipid $+6 \mathrm{U} / \mathrm{h}$ heparin) or an equivalent volume of saline (Control) was infused for $5 \mathrm{~h}(t=-300$ to $0 \mathrm{~min}$ ). Arterial blood samples were taken hourly. At $t=0 \mathrm{~min}$, mice were killed with pentobarbital sodium, and skeletal muscle groups were excised, snap-frozen in liquid nitrogen and stored at $-80^{\circ} \mathrm{C}$.

Protocol 2: mice received Lipid treatment or Control as above, followed by a $2 \mathrm{~h}$ hyperinsulinaemic-euglycaemic clamp (insulin clamp; $4 \mathrm{mU} \mathrm{kg}{ }^{-1} \min ^{-1}$ [19]) beginning at $t=0 \mathrm{~min}$. Lipid or Control treatments were continued throughout the insulin clamp. To prevent a fall of $>5 \%$ in packed cell volume during the insulin clamp, mice received saline-washed erythrocytes from donors throughout the experimental period $(1 \mu \mathrm{l} / \mathrm{min}$ from $t=-240$ to $0 \mathrm{~min} ; 4 \mu \mathrm{l} / \mathrm{min}$ from $t=0$ to $120 \mathrm{~min}$ ). Following the final blood sample, mice were anaesthetised and killed, and tissues were collected.

Protocol 3: mice received Lipid treatment for $5 \mathrm{~h}$. At $t=-240 \mathrm{~min}$ mice also received a continuous infusion of AICAR ( $1 \mathrm{mg} \mathrm{kg}^{-1} \mathrm{~min}^{-1}$ ) (Toronto Research Chemicals, Toronto, ON, Canada) or an equal volume of saline as a control. At $t=0$ min mice underwent a $2 \mathrm{~h}$ insulin clamp as in Protocol 2, with Lipid treatment and AICAR or saline infusion continuing throughout the insulin clamp. After the final blood sample, $50 \mu \mathrm{l}$ yellow Dye-Trak microspheres $(15 \mu \mathrm{m}$; Triton Technology, San Diego, CA, USA) were injected into the carotid artery, followed by a small flush of saline, to assess per 
Fig. 1 Schematic outlines of the four different infusion protocols used in $\mathrm{C} 57 \mathrm{BL} / 6 \mathrm{~J}$ wild-type mice, i.e. (a) Protocol 1, (b) Protocol 2, (c) Protocol 3 and (d) Protocol 4. Arrow (c), bolus administration of $2-\left[{ }^{14} \mathrm{C}\right]$ DG at $78 \mathrm{~min}$

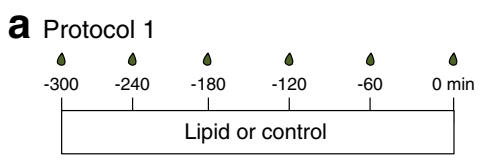

b Protocol 2
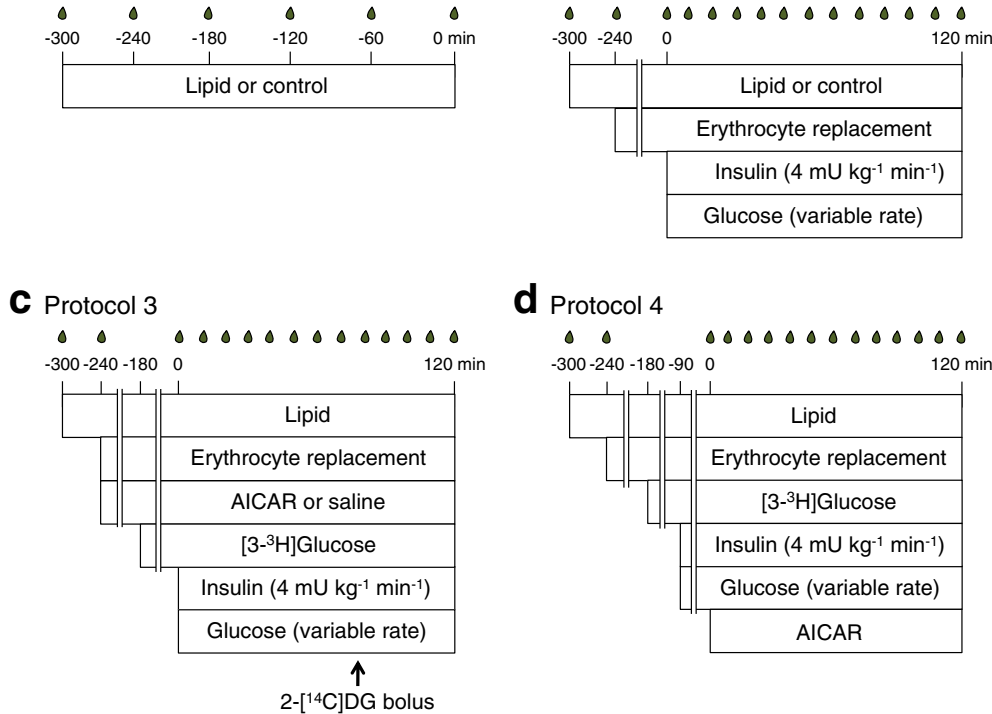

cent of cardiac output to gastrocnemius muscle $\left(\% \mathrm{Q}_{\mathrm{G}}\right)$. Mice were anaesthetised and killed, and tissues were collected. In a subset of mice, rates of whole-body and tissuespecific glucose fluxes were also determined using $\left[3-{ }^{3} \mathrm{H}\right]$ glucose and 2-deoxy $\left[{ }^{14} \mathrm{C}\right]$ glucose $\left(2-\left[{ }^{14} \mathrm{C}\right] \mathrm{DG}\right)$, respectively $[19,20]$. To determine endogenous (Endo) rates of glucose appearance $\left(R_{\mathrm{a}}\right)\left(\right.$ Endo $\left.R_{\mathrm{a}}\right)$ and glucose disappearance $\left(R_{\mathrm{d}}\right)$, a $74 \mathrm{kBq}$ bolus of $\left[3-{ }^{3} \mathrm{H}\right]$ glucose was administered at $t=-180 \mathrm{~min}$, followed by a continuous $5.9 \mathrm{kBq} / \mathrm{min}$ infusion of $\left[3-{ }^{3} \mathrm{H}\right]$ glucose. At $t=78 \mathrm{~min}$, a $481 \mathrm{kBq}$ bolus of $2-\left[{ }^{14} \mathrm{C}\right] \mathrm{DG}$ was injected into the jugular vein to determine tissue-specific indices of muscle glucose uptake $\left(R_{\mathrm{g}}\right)$.

Protocol 4: mice received Lipid treatment for $5 \mathrm{~h}$. At $t=-90 \mathrm{~min}$ the insulin clamp commenced and at $t=$ 0 min AICAR ( $\left.1 \mathrm{mgkg}^{-1} \mathrm{~min}^{-1}\right)$ was infused for $2 \mathrm{~h}$. Lipid treatment was infused throughout this period. Endo $R_{\mathrm{a}}$ and $R_{\mathrm{d}}$ were determined. Saline-washed erythrocytes were given as for Protocol 2.

In a separate study, $\alpha 2-K D$ mice that had fasted for $5 \mathrm{~h}$ underwent a standard $2 \mathrm{~h}$ insulin clamp [19] to determine insulin-stimulated glycogen synthesis.

Plasma analyses Arterial glucose was determined from $\sim 5 \mu \mathrm{l}$ arterial blood using a monitor (Accu-Chek Advantage; Roche Diagnostics, Indianapolis, IN, USA). Immunoreactive plasma insulin was assayed with a double antibody method [21]. Plasma NEFA were measured spectrophotometrically (NEFA C kit; Wako Chemicals, Richmond, VA, USA). Plasma lactate was measured enzymatically [20]. Plasma for $\left[3-{ }^{3} \mathrm{H}\right]$ glucose and $2-\left[{ }^{14} \mathrm{C}\right] \mathrm{DG}$ measurements was deproteinised with $\mathrm{Ba}(\mathrm{OH})_{2}$ and $\mathrm{ZnSO}_{4}$, and an aliquot was counted either directly or after being dried to remove ${ }^{3} \mathrm{H}_{2} \mathrm{O}$ [19].
Tissue preparation Whole-cell lysates from the gastrocnemius muscle were prepared as described [20]. Protein content was determined using the Bradford method. Following extraction with perchloric acid, adenine nucleotides were measured by HPLC [22] and glucose-6-phosphate via enzymatic methods [23]. Tissue samples for 2-[ $\left[{ }^{14} \mathrm{C}\right] \mathrm{DG}$ and 2-[ $\left[{ }^{14} \mathrm{C}\right] \mathrm{DG}-$ phosphate were determined as described [20]. Glycogen was determined using the method of Chan and Exton [24].

Assays AMPK $\alpha 2$ and $-\alpha 1$ activity was measured following immunoprecipitation as described [20]. AMPK activity in the immune complexes was measured in the presence of $200 \mu \mathrm{mol} / \mathrm{l}$ AMP and calculated as incorporation of phosphate into the SAMS peptide (100 $\mu \mathrm{mol} / \mathrm{l}$; GenWay Biotech, San Diego, CA, USA), expressed as pmol $\mathrm{min}^{-1} \mathrm{mg}^{-1}$ of protein subjected to immunoprecipitation. iNOS activity was measured as described previously for total NOS activity [20], except that EGTA (1 mmol/l) was added to the assay buffer to inhibit $\mathrm{Ca}^{2+}$-dependent NOS activity (i.e. neuronal and endothelial NOS isozymes) and the assay was performed for $25 \mathrm{~min}$ at $37^{\circ} \mathrm{C}$. iNOS activity was calculated as conversion of $\mathrm{L}-\left[{ }^{3} \mathrm{H}\right]$ arginine to $\mathrm{L}-\left[{ }^{3} \mathrm{H}\right]$ citrulline in pmol $\mathrm{min}^{-1} \mathrm{mg}^{-1}$ of protein. Glycogen synthase (GS) and glycogen phosphorylase activity was assessed as described [25].

Immunoblotting AMPK $\alpha 2$ protein levels and acetyl-CoA carboxylase (ACC) $\beta$ abundance/Ser ${ }^{22}$ phosphorylation were determined from $100 \mu \mathrm{g}$ whole-cell lysate. Proteins were separated using gels (NuPAGE 4-12\% (vol./vol.) BisTris Gels; Invitrogen, Carlsbad, CA, USA). Blots were probed with an AMPK $\alpha 2$ goat polyclonal (Santa Cruz, Santa Cruz, CA, USA) or ACC $\beta \mathrm{Ser}^{221}$ rabbit polyclonal antibody (Cell Signaling, MA, USA), respectively. ACC $\beta$ protein abundance was detected using IRDye 800-labelled 
streptavidin (Rockland Immunochemicals, Gilbertsville, PA, USA). Protein levels were normalised to GAPDH (glyceraldehyde 3-phosphate dehydrogenase; Abcam, Cambridge, MA, USA). Antibody binding for AMPK $\alpha 2$ and ACC $\beta \operatorname{Ser}^{221}$ was detected with an IRDye 800-conjugated anti-goat or anti-rabbit IgG. An IRDye 700-conjugated antimouse IgG secondary antibody (Rockland Immunochemicals) was used for GAPDH. iNOS abundance was determined in Protocol 1 by immunoprecipitation of iNOS on $500 \mu \mathrm{g}$ protein using Recomb protein A beads and $2 \mu \mathrm{g}$ of a mouse iNOS monoclonal antibody (BD Biosciences, San Jose, CA, USA). In Protocol 3, iNOS abundance was determined from $100 \mu \mathrm{g}$ whole-cell lysate.

Calculations Endo $R_{\mathrm{a}}$ and $R_{\mathrm{d}}$ were determined using Steele's non-steady-state equations [26]. Endo $R_{\mathrm{a}}$ was determined by subtracting the exogenous glucose infusion rate (GIR) from total $R_{\mathrm{a}}$. Whole-body glycolytic rates were estimated from the increment per unit time of ${ }^{3} \mathrm{H}_{2} \mathrm{O}$ multiplied by estimated body water (assumed to be $60 \%$ of body weight) and divided by $\left[3-{ }^{3} \mathrm{H}\right]$ glucose-specific activity. The appearance of ${ }^{3} \mathrm{H}_{2} \mathrm{O}$ was determined by linear regression of samples from $t=80$ to $120 \mathrm{~min}$. The whole-body glycogen synthesis rate was calculated as the $R_{\mathrm{d}}$ minus the whole-body glycolytic rate. To determine insulin-stimulated muscle glycogen synthesis, the specific activity of gastrocnemius $\left[3-{ }^{3} \mathrm{H}\right]$ glucose was multiplied by gastrocnemius glycogen content and divided by the specific activity of plasma $\left[3-{ }^{3} \mathrm{H}\right]$ glucose. Indices of tissue-specific clearance of $2-\left[{ }^{14} \mathrm{C}\right] \mathrm{DG}\left(K_{\mathrm{g}}\right)$ and $R_{\mathrm{g}}$ were calculated as described [27]. Per cent of cardiac output to gastrocnemius muscle was calculated as described $[20,28]$.

Statistical analyses Data are mean \pm SEM. Statistical analysis was performed using a Student's $t$ test, one-way ANOVA or two-way repeated measures ANOVA where appropriate, with the statistical software package SigmaStat (Systat Software, San Jose, CA, USA). If the ANOVA was significant $(p<0.05)$, specific differences were located using Fisher's least significant difference (LSD) test.

\section{Results}

Acute lipid-induced insulin resistance impairs skeletal muscle AMPK 2 activation and enhances iNOS levels After $1 \mathrm{~h}$ of lipid treatment (Protocol 1; Fig. 1a), plasma NEFA levels were significantly elevated compared with Control $(2.7 \pm 0.5$ vs $1.2 \pm 0.2 \mathrm{mmol} / \mathrm{l}$, respectively; $p<0.05)$ and remained elevated over the subsequent $4 \mathrm{~h}$ (Fig. 2a). Lipid treatment did not alter arterial glucose $(6.0 \pm 0.4$ vs $5.7 \pm 0.3 \mathrm{mmol} / \mathrm{l}$ for Control) or plasma insulin levels $(0.46 \pm 0.03$ vs $0.36 \pm$

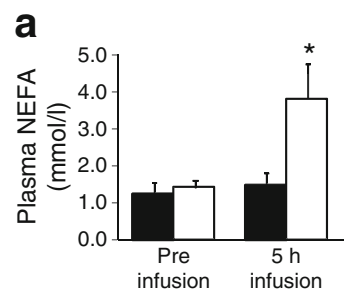

b
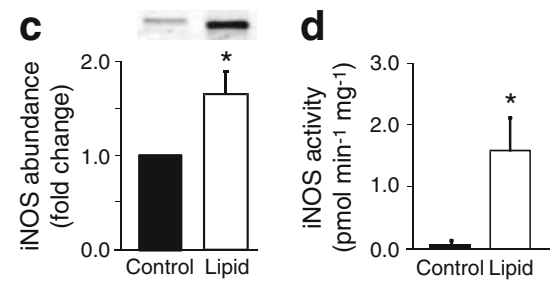

Fig. 2 Effect of a $5 \mathrm{~h}$ infusion of $5 \mathrm{ml} \mathrm{kg}^{-1} \mathrm{~h}^{-1}$ Intralipid $+6 \mathrm{U} / \mathrm{h}$ heparin (Lipid treatment) or of an equivalent volume of saline (Control) on (a) plasma NEFA levels, (b) gastrocnemius AMPK $\alpha 2$ and $-\alpha 1$ activity, (c) iNOS abundance (as fold change vs control) and (d) iNOS activity. Data are mean \pm SEM for $n=5$ per group; ${ }^{*} p<0.05$ vs corresponding control value

$0.10 \mathrm{nmol} / \mathrm{l}$, respectively). Lipid treatment reduced gastrocnemius AMPK $\alpha 2$ activity by $25 \pm 7 \%$ compared with Control $(p<0.05)$ (Fig. 2b). This was not due to alterations in AMPK $\alpha 2$ protein levels $(82 \pm 4$ vs $83 \pm 2$ arbitrary units for Control) or adenine nucleotide levels (Table 1). Gastrocnemius AMPK $\alpha 1$ activity (Fig. 2b) and ACC $\beta$ Ser $^{221}$ phosphorylation (Fig. 3f) were not significantly altered. Lipid treatment increased gastrocnemius iNOS abundance (Fig. 2c) and activity (Fig. 2d) 1.5-fold.

Plasma NEFA levels remained elevated throughout the subsequent $2 \mathrm{~h}$ insulin clamp (Protocol 2; Fig. 1b) in Lipid treatment mice (Fig. 3a), which were also insulin-resistant, as evidenced by a $51 \pm 6 \%$ reduction in the GIR required to maintain euglycaemia during the insulin clamp (Fig. 3b, c). This occurred despite significantly higher plasma insulin levels $(2.1 \pm 0.3$ vs $1.0 \pm 0.1 \mathrm{nmol} / 1$ for Control; $p<0.001)$. In Control mice, insulin markedly suppressed AMPK $\alpha 2$ and $-\alpha 1$ activity (Fig. 3d, e), and ACC $\beta \operatorname{Ser}^{221}$ phosphorylation (Fig. 3f). Insulin suppressed AMPK $\alpha 2$ activity in Lipid treatment mice (Fig. 3d), although the relative suppression was attenuated compared with Control mice $(45 \pm 3$ vs $63 \pm$ $3 \%$, respectively; $p=0.001$ ). Insulin did not suppress AMPK $\alpha 1$ activity in Lipid treatment mice (Fig. 3e), while ACC $\beta$ Ser $^{221}$ phosphorylation was suppressed to similar levels to those in Control mice (Fig. 3f).

AICAR increases skeletal muscle AMPK 2 activity Given that Lipid treatment-induced impairment of skeletal muscle AMPK signalling was associated with insulin resistance and enhanced iNOS activation, we determined whether activation of AMPK $\alpha 2$ (via the AMPK activator AICAR) during lipid infusion (Protocol 3; Fig. 1c) could suppress iNOS 
Table 1 Adenine nucleotide levels in gastrocnemius muscle of C57BL/6J wild-type mice following Lipid treatment

\begin{tabular}{llll}
\hline Variable & ATP & ADP & AMP \\
\hline Control & $5.38 \pm 0.23$ & $0.83 \pm 0.06$ & $0.16 \pm 0.02$ \\
Lipid treatment & $5.29 \pm 0.53$ & $0.82 \pm 0.08$ & $0.17 \pm 0.03$ \\
\hline
\end{tabular}

Values are in $\mu \mathrm{mol} / \mathrm{g}$, and are given as mean \pm SEM for $n=5$ (Control) and $n=6$ (Lipid treatment)

Lipid treatment was by $5 \mathrm{~h}$ infusion of $5 \mathrm{ml} \mathrm{kg}^{-1} \mathrm{~h}^{-1}$ Intralipid $+6 \mathrm{U} / \mathrm{h}$ heparin or by an equivalent volume of saline (Control)

activation, thus improving insulin sensitivity. AICAR was infused at $1 \mathrm{mg} \mathrm{kg}^{-1} \mathrm{~min}^{-1}$ for the last $4 \mathrm{~h}$ of the Lipid treatment ( $\mathrm{t}=-240$ to $0 \mathrm{~min}$ ) and continued throughout the $2 \mathrm{~h}$ insulin clamp ( $\mathrm{t}=0-120 \mathrm{~min})$. Previous studies in rodents and humans assessing AICAR-stimulated muscle glucose metabolism in vivo have used doses ranging from 0.125 to $10 \mathrm{mg} \mathrm{kg}^{-1} \mathrm{~min}^{-1}$ [29-34]. A dose of $1 \mathrm{mg} \mathrm{kg}^{-1}$ $\mathrm{min}^{-1}$ required an infusion of exogenous glucose to maintain arterial glucose at levels similar to those in saline-
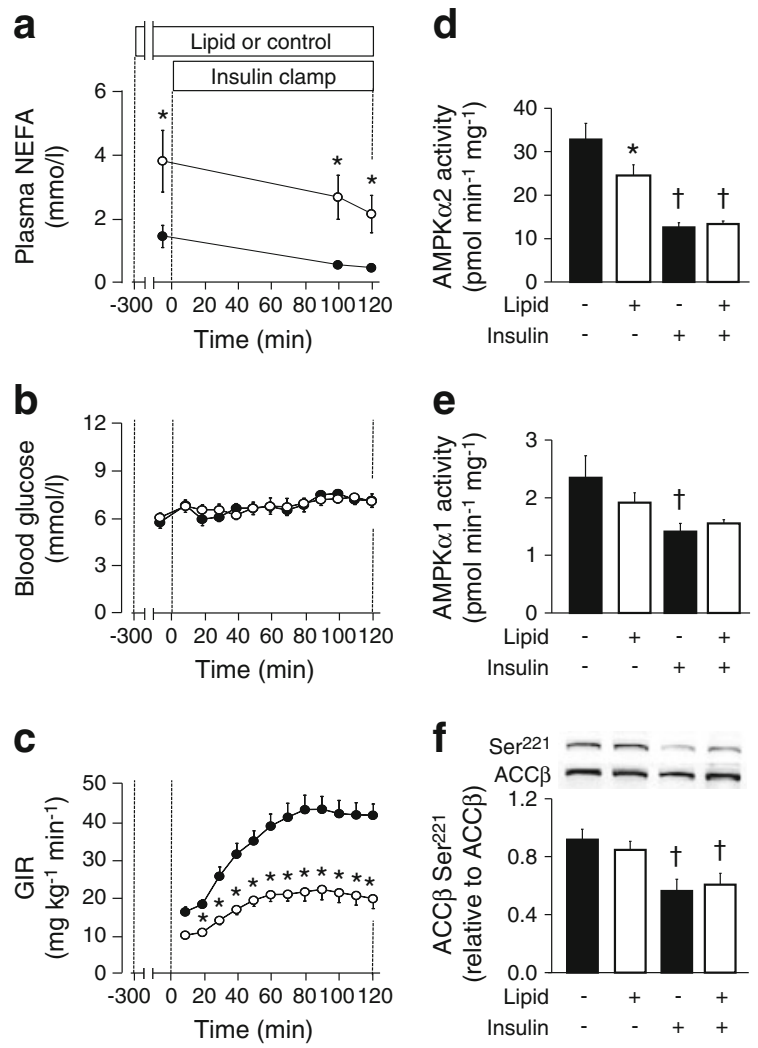

Fig. 3 (a) Plasma NEFA levels, (b) arterial glucose levels and (c) GIR prior to $(-300$ to $0 \mathrm{~min}$ ) and during (0 to $120 \mathrm{~min}$ ) a $2 \mathrm{~h}$ hyperinsulinaemic-euglycaemic clamp as described in the Methods, in mice that received $5 \mathrm{ml} \mathrm{kg} \mathrm{k}^{-1}$ Intralipid $+6 \mathrm{U} / \mathrm{h}$ heparin from -300 to $120 \mathrm{~min}$. White circles, Lipid treatment; black circles, Control. (d) Gastrocnemius AMPK $\alpha 2$ activity, (e) AMPK $\alpha 1$ activity and (f) ACC $\beta$ $\operatorname{Ser}^{221}$ phosphorylation. Data are mean \pm SEM for $n=5-9$ per group; ${ }^{*} p<0.05$ vs corresponding Control value; ${ }^{\dagger} p<0.05$ vs corresponding non-insulin value infused mice. Preliminary experiments confirmed that the dose of exogenous glucose required at $1 \mathrm{mg} \mathrm{kg}^{-1} \mathrm{~min}^{-1}$ AICAR (glucose $10 \pm 3 \mathrm{mg} \mathrm{kg}^{-1} \mathrm{~min}^{-1}, n=7$ ) did not differ from that required at $10 \mathrm{mg} \mathrm{kg}^{-1} \mathrm{~min}^{-1}$ AICAR (glucose $13 \pm 2 \mathrm{mg} \mathrm{kg}^{-1} \mathrm{~min}^{-1}, n=9$ ).

Gastrocnemius ATP, ADP and AMP levels were not altered in response to AICAR by the end of the insulin clamp (Fig. 4a). However, 5-amino-4-imidazolecarboxamide ribotide (ZMP) levels increased to $\sim 75 \%$ of AMP levels (Fig. 4b). In line with increased ZMP, gastrocnemius AMPK $\alpha 2$ activity (Fig. 4c) and ACC $\beta$ Ser $^{221}$ phosphorylation (Fig. 4 d) were $\sim 2.5$-fold greater at the end of the insulin clamp in AICAR-infused mice. AMPK $\alpha 1$ activity remained unchanged (data not shown). The increase in AMPK $\alpha 2$ activity did not impact on iNOS levels (Fig. 4e) or iNOS activity (Fig. 4f).

AICAR infusion does not improve whole-body insulin sensitivity during acute hyperlipidaemia Infusion of AICAR during Lipid treatment (i.e. $\mathrm{t}=-240$ to $0 \mathrm{~min}$ ) did not alter plasma insulin levels (Fig. 5a). However, AICAR did require an exogenous glucose infusion, with $10 \pm 3 \mathrm{mg} \mathrm{kg}^{-1}$ $\min ^{-1}$ needed at $\mathrm{t}=0 \mathrm{~min}$ to maintain glucose at similar levels to those in saline-infused mice (Fig. 5b, c). The GIR requirement in response to AICAR infusion was due to suppressed Endo $R_{\mathrm{a}}$ (Fig. 5d), as opposed to altered $R_{\mathrm{d}}$, which was unchanged in AICAR- vs saline-infused mice (Fig. 5e). AICAR infusion also significantly increased plasma lactate levels (Fig. 5f).

AICAR infusion prior to and during the $2 \mathrm{~h}$ insulin clamp did not alter insulin-stimulated GIR (Fig. 5c). Insulin as such suppressed Endo $R_{\mathrm{a}}$, while AICAR plus insulin exerted an additive effect on $\mathrm{Endo} R_{\mathrm{a}}$ suppression, resulting in reduced absolute rates of Endo $R_{\mathrm{a}}$ at the end of the insulin clamp compared with saline-infused mice (Fig. 5d). However, the insulin-stimulated reduction of $E n d o R_{\mathrm{a}}$ (i.e. from $\mathrm{t}=0-120 \mathrm{~min})$ was similar between AICAR- and salineinfused mice (decreases of $15 \pm 3$ vs $13 \pm 5 \mathrm{mg} \mathrm{kg}^{-1} \mathrm{~min}^{-1}$, respectively). Insulin increased $R_{\mathrm{d}}$ (Fig. $5 \mathrm{e}$ ), however no additive effect of AICAR was observed. Plasma lactate levels at the end of the insulin clamp remained elevated in AICAR-infused mice (Fig. 5f). AICAR did not alter the per cent cardiac output to gastrocnemius muscle at the end of the insulin clamp (data not shown).

The results described above suggest that a pharmacological increase in skeletal muscle AMPK $\alpha 2$ activity (via AICAR) is not sufficient to induce alterations in wholebody glucose disposal (i.e. $R_{\mathrm{d}}$ ). To rule out the possibility that the order of AICAR and insulin infusions was a factor in determining results, a subset of mice underwent an insulin clamp that commenced during the last $90 \mathrm{~min}$ of Lipid treatment (i.e. $\mathrm{t}=-90$ to $0 \mathrm{~min}$ ), followed by a $2 \mathrm{~h}$ AICAR infusion (i.e. $\mathrm{t}=0-120 \mathrm{~min}$; Protocol 4; Fig. 1d). Insulin 

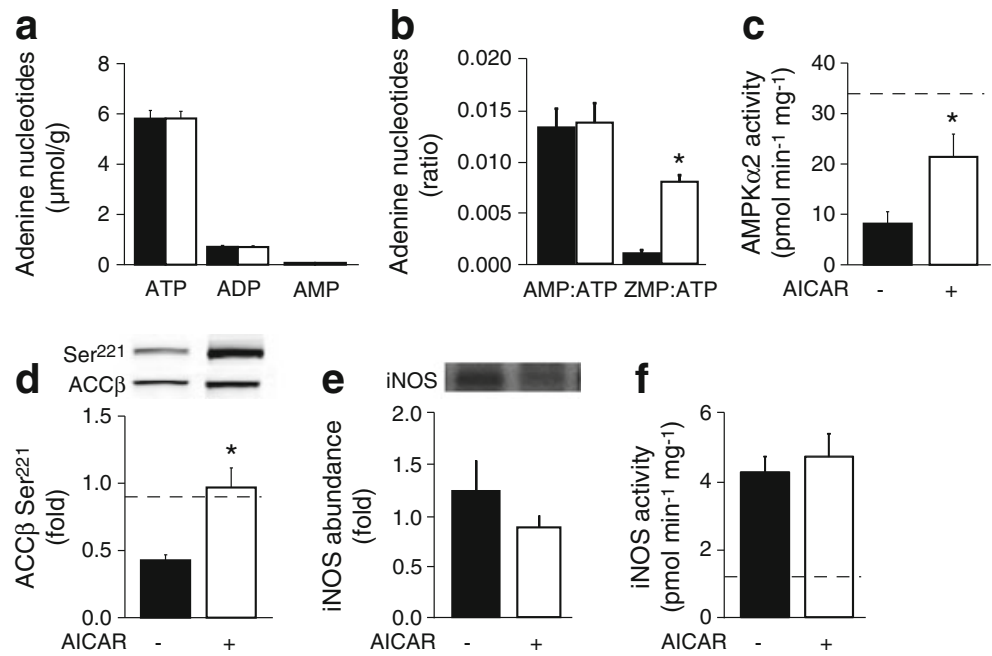

Fig. 4 AICAR $\left(1 \mathrm{mg} \mathrm{kg}^{-1} \mathrm{~min}^{-1}\right)$ (white bars) or an equivalent volume of saline (black bars) was infused during the last $4 \mathrm{~h}$ of a $5 \mathrm{~h}$ lipid infusion $\left(5 \mathrm{ml} \mathrm{kg}^{-1} \mathrm{~h}^{-1}\right.$ Intralipid $+6 \mathrm{U} / \mathrm{h}$ heparin) and a subsequent $2 \mathrm{~h}$ insulin clamp. (a, b) Gastrocnemius adenine nucleotide levels, (c) AMPK $\alpha 2$ activity, (d) ACC $\beta \operatorname{Ser}^{221}$ phosphorylation (relative to

infusion from $\mathrm{t}=-90$ to $0 \mathrm{~min}$ increased GIR to $40 \pm 2 \mathrm{mg}$ $\mathrm{kg}^{-1} \mathrm{~min}^{-1}$ and increased $R_{\mathrm{d}}$ from $20 \pm 1$ to $35 \pm 2 \mathrm{mg} \mathrm{kg}^{-1}$ $\min ^{-1}(p<0.01)$. However, the addition of AICAR from $\mathrm{t}=0-120 \mathrm{~min}$ did not further alter GIR $\left(42 \pm 3 \mathrm{mg} \mathrm{kg}^{-1}\right.$ $\left.\min ^{-1}\right)$ or $R_{\mathrm{d}}\left(36 \pm 3 \mathrm{mg} \mathrm{kg}{ }^{-1} \mathrm{~min}^{-1}\right)$ compared with the preceding $90 \mathrm{~min}$ insulin infusion.

\section{AICAR infusion in vivo increases rates of insulin-stimulated} glycogen synthesis Despite no change being observed in $R_{\mathrm{d}}$, whole-body glycolytic rates, interestingly, were suppressed during the $4 \mathrm{~h}$ AICAR infusion (i.e. $\mathrm{t}=-240$ to $0 \mathrm{~min}$ ), while glycogen synthesis rates were elevated (Fig. 6a, b). Insulin suppressed glycolytic rates and increased synthesis rates regardless of AICAR or saline infusion. However, glycolysis remained attenuated and synthesis enhanced in mice receiving AICAR and insulin. Likewise, gastrocnemius glycogen levels were significantly elevated in AICAR-plus insulin-infused mice (Fig. 6c), as was the rate of $\left[3-{ }^{3} \mathrm{H}\right]$ glucose incorporated into muscle glycogen (i.e. enhanced glycogen synthesis) (Fig. 6d). However, gastrocnemius $R_{\mathrm{g}}$ did not differ between AICAR plus insulin and saline plus insulin mice (Fig. 6e), findings also observed in other muscle groups (data not shown). Glucose-6-phosphate levels were elevated $\sim 30 \%$ in mice infused with AICAR and insulin ( $p=0.1$ ) (Fig. 6f), while GS (Fig. 6g) and glycogen phosphorylase (Fig. 6h) activities were unchanged.

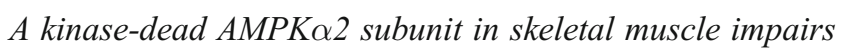
insulin-mediated glycogen synthesis in vivo The above data indicated a role for AMPK $\alpha 2$ in determining the cellular fate of glucose. To determine whether activation of AMPK $\alpha 2$, as opposed to an AMPK $\alpha 2$-independent effect
ACC $\beta$ ), (e) iNOS abundance (relative to GAPDH) and (f) iNOS activity were determined. Dashed line (c, $\mathbf{d}, \mathbf{f})$, values in mice following $5 \mathrm{~h}$ of Lipid treatment or Control (i.e. in the absence of insulin). Data are mean \pm SEM for $n=11-12(\mathbf{a}, \mathbf{b})$ and $n=5-7(\mathbf{c}-\mathbf{f}) ;{ }^{*} p<0.05$ vs corresponding saline value

of AICAR, accentuated insulin-stimulated glycogen synthesis, lean, otherwise healthy $\alpha 2-\mathrm{KD}$ mice underwent an insulin clamp. Such $\alpha 2-\mathrm{KD}$ mice have essentially no skeletal muscle AMPK $\alpha 2$ activity at rest or in response to physiological stimuli such as exercise [20]. Interestingly, iNOS activity was significantly elevated in $\alpha 2-\mathrm{KD}$ mice following a $5 \mathrm{~h}$ fast $\left(2.2 \pm 0.4 \mathrm{vs} 0.5 \pm 0.3 \mathrm{pmol} \mathrm{min}^{-1} \mathrm{mg}^{-1}\right.$ for wild-type; $p<0.02$ ).

No differences between $\alpha 2-\mathrm{KD}$ and wild-type mice were observed with respect to blood glucose, GIR, Endo $R_{\mathrm{a}}$, and $R_{\mathrm{d}}$ during the insulin clamp (Fig. 7a-d). However, in $\alpha 2-\mathrm{KD}$ mice, skeletal muscle glycogen was significantly lower (Fig. 7e), the rate of $\left[3-{ }^{3} \mathrm{H}\right]$ glucose incorporation into skeletal muscle glycogen was reduced by $47 \pm 10 \%$ (Fig. 7 f) and there was a strong tendency for reduced rates of whole-body glycogen synthesis $(0.35 \pm 0.07$ vs $0.51 \pm 0.05$ for wild-type; $p=0.08$ ). Thus, a functionally inactive AMPK $\alpha 2$ subunit in skeletal muscle is associated with impaired insulinstimulated glycogen synthesis.

\section{Discussion}

Obesity and insulin resistance are associated with impaired AMPK $\alpha 2$ activation [14] and enhanced iNOS abundance/ activation [9] in skeletal muscle. Direct evidence for an AMPK $\alpha 2-$ iNOS axis is unclear and the ability to test a casual relationship is confounded by the many complications associated with these chronic metabolic disease states. Here, we show that in healthy mice, the induction of acute hyperlipidaemia reduces skeletal muscle AMPK $\alpha 2$ activity and increases iNOS levels/activation in vivo. However, a 

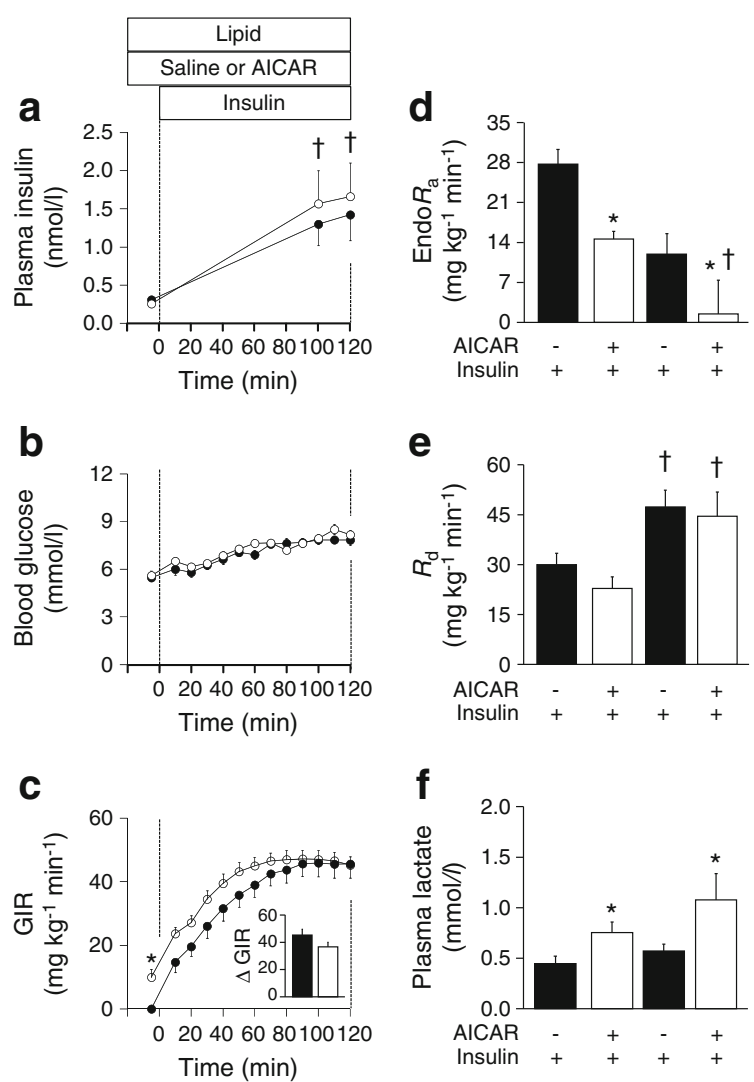

Fig. 5 Plasma insulin levels (a), blood glucose levels (b) and GIR, with insulin-induced change in GIR $(\Delta \mathrm{GIR})$ (c) during a $2 \mathrm{~h}$ insulin clamp, which was preceded by a $5 \mathrm{~h}$ lipid infusion $\left(5 \mathrm{ml} \mathrm{kg}^{-1} \mathrm{~h}^{-1}\right.$ Intralipid $+6 \mathrm{U} / \mathrm{h}$ heparin $)$ in conjunction with AICAR $\left(1 \mathrm{mg} \mathrm{kg}^{-1}\right.$ $\mathrm{min}^{-1}$ ) (white circles) or an equivalent volume of saline (black circles), which was infused during the last $4 \mathrm{~h}$ of the lipid infusion. The lipid and AICAR or saline infusions were continued throughout the clamp. (d) The effect of the above treatment on Endo $R_{\mathrm{a}}$, (e) $R_{\mathrm{d}}$ and (f) plasma lactate levels. Data are mean \pm SEM for $n=11-12$; ${ }^{*} p<0.05$ for main effect, AICAR; ${ }^{\dagger} p<0.05$ for main effect, insulin

reduction of AMPK $\alpha 2$ activity is not required for the lipidinduced increase of iNOS. Nor is an active AMPK $\alpha 2$ subunit required for improved insulin-stimulated muscle glucose uptake or whole-body insulin action. Indeed, rescue of the lipidinduced impairment of AMPK $\alpha 2$ activity via AICAR infusion did not improve whole-body insulin-stimulated glucose uptake. Rather, in lipid-infused mice, pharmacological activation of AMPK $\alpha 2$ in skeletal muscle was associated with an increase in the percentage of glucose taken up and directed into glycogen under insulin-stimulated conditions. This finding was supported by the demonstration of impaired insulinstimulated glycogen synthesis, but not glucose uptake, in lean mice expressing a dominant-negative mutation of the Ampko2 subunit in skeletal muscle.

A major question arising from our collective studies is how AICAR can alter muscle glycogen synthesis independently of alterations in key determinants of glucose uptake and glycogen synthesis and degradation. Our finding is not unique. In high fat-fed rats, the injection of AICAR $(250 \mathrm{mg} / \mathrm{kg}) 24 \mathrm{~h}$ prior to an insulin clamp did not alter insulin-stimulated $R_{\mathrm{d}}$ or $R_{\mathrm{g}}$ in red quadriceps muscle, yet red quadriceps glycogen synthesis increased [5]. In that study, glucose-6-phosphate, GS and glycogen phosphorylase were not assessed. While we do not have conclusive evidence, we believe that the effect of AICAR on the modulation of muscle glycogen synthesis is mediated via AMPK $\alpha 2$. It has been shown that the addition of AICAR ( $2 \mathrm{mmol} / \mathrm{l}$ ) to rat muscle made insulin-resistant via palmitate incubation improved insulin-stimulated glycogen synthesis $(6 \mathrm{nmol} / \mathrm{l}$ insulin) in vitro, an effect which was ablated in the presence of an AMPK inhibitor [35]. Nevertheless, in that study [35] AICAR did induce a small, albeit significant increase in insulin-stimulated glucose transport at $6 \mathrm{nmol} / \mathrm{l}$ insulin, and a $\sim 65 \%$ increase in glucose-6-phosphate levels. Glucose-6phosphate levels were elevated $\sim 30 \%$ in our study, and while this was not statistically significant $(p=0.1)$, one cannot discount the possibility that this increase is enough to elicit a change in intramuscular glucose metabolism in vivo. Interestingly, AICAR also increases glycogen synthesis in insulinresistant muscle in vitro in response to $0.6 \mathrm{nmol} / \mathrm{l}$ insulin [35]. Unfortunately, glucose-6-phosphate levels and glucose transport rates were not assessed at this tenfold lower insulin dose, although one would expect these variables to be attenuated.

It cannot be ruled out that our findings are in part due to offtarget effects of AICAR. Other, more specific AMPK activators are now available (e.g. A-769662). However, it has been shown that this compound is selective for AMPK $\beta 1$ heterotrimeric complexes, which represent a small fraction of AMPK heterotrimers in skeletal muscle [36]. As with AICAR, off-target effects of A-769662 have also been observed [36]. Alternatively, while the majority of evidence suggests that AICAR-AMPK $\alpha 2$ is not involved in the regulation of glycogen phosphorylase [37, 38], it is possible that AICARAMPK $\alpha 2$ altered the targeting of GS. However, in insulinresistant muscle, activation of AMPK via AICAR does not alter GS activity or key GS phosphorylation sites [35]. Similarly, the total activity of protein phosphatase-1, a major glycogen targeting subunit [39], appears to be unaltered in response to an Intralipid infusion [40].

A key difference between our current study and almost all previous in vivo studies is the dose of AICAR infused and also the plasma insulin concentration. This is not a trivial point. Thus here we observed increased AMPK $\alpha 2$ activity at $1 \mathrm{mg}$ $\mathrm{kg}^{-1} \mathrm{~min}^{-1}$ AICAR, a much lower dose than the 7.5 to $10 \mathrm{mg}$ $\mathrm{kg}^{-1} \min ^{-1}$ used by others $[29,30,33]$, who also observed elevated $R_{\mathrm{d}}$ and muscle glucose uptake. Given that AICAR increases ZMP (an AMP analogue) and thus ZMP:ATP, it is possible that the elevated rates of muscle glucose uptake seen with higher AICAR doses are at least partially AMPK $\alpha 2$ independent. An example of this relates to gene transcription. Stoppani et al [34] saw increased AMPK $\alpha 2$ activation and enhanced transcription of uncoupling protein 3 and hexokinase II in response to $1,000 \mathrm{mg} / \mathrm{kg}$ AICAR, an effect that was 
a

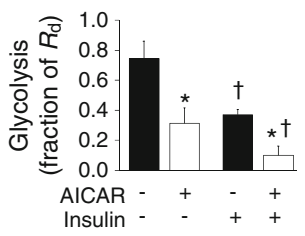

b

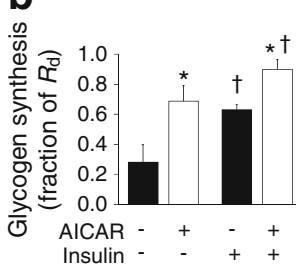

C

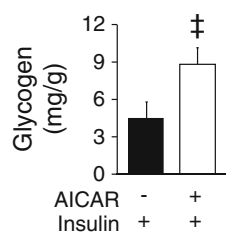

d

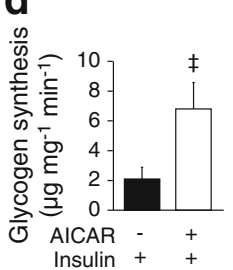

e

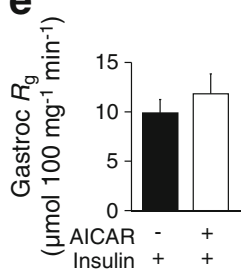

f

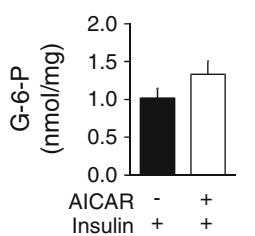

g

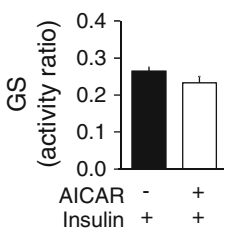

h

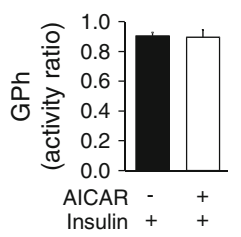

Fig. 6 The effect of a $4 \mathrm{~h}$ AICAR infusion $\left(1 \mathrm{mg} \mathrm{kg}^{-1} \mathrm{~min}^{-1}\right)$ or an equivalent volume of saline, followed by a $2 \mathrm{~h}$ insulin clamp on (a) whole-body rates of glycolysis and (b) glycogen synthesis, expressed as a fraction of whole-body $R_{\mathrm{d}}$. Lipid treatment at $5 \mathrm{ml} \mathrm{kg}^{-1} \mathrm{~h}^{-1}$ Intralipid $+6 \mathrm{U} / \mathrm{h}$ heparin was administered throughout. (c) Also shown are gastrocnemius glycogen content, (d) $\left[3-{ }^{3} \mathrm{H}\right]$ glucose incorporation into

accompanied by hypoglycaemia and elevated blood lactate levels. Reducing the total AICAR dose to $30 \mathrm{mg} / \mathrm{kg}$ still increased skeletal muscle AMPK $\alpha 2$ activation and transcription of uncoupling protein 3 and hexokinase II, but did not alter blood glucose or lactate levels [34]. Similarly, it has been shown that AICAR-, but not insulin-stimulated glycogen synthesis is impaired in $\alpha 2-\mathrm{KD}$ mice in vitro [38]. This differs from our current finding, whereby $\alpha 2-\mathrm{KD}$ mice exhibited a reduction of insulin-stimulated glycogen synthesis. However, Hunter and colleagues incubated muscles with $60 \mathrm{nmol} / \mathrm{l}$ of insulin [38], well above the higher end of the physiological range used in the present study (average of $\sim 1.5 \mathrm{nmol} / 1$ across all studies).

Our findings are consistent with studies showing that: (1) a constitutively active AMPK $\alpha 2$ subunit (via a R225Q mutation in Ampk $\gamma 3$ [also known as Prkag3]) is associated with elevated muscle glycogen levels following feeding, glycogen, (e) the glucose metabolic index $\left(R_{\mathrm{g}}\right)$, (f) glucose-6phosphate (G-6-P) levels, (g) GS activity and (h) glycogen phosphorylase $(\mathrm{GPh})$ activity under the above conditions. Data are mean \pm SEM for $n=6$ per group; ${ }^{*} p<0.05$ for main effect, AICAR; ${ }^{\dagger} p<0.05$ for main effect, insulin; ${ }^{\ddagger} p<0.05$ vs corresponding saline value

fasting or the post-exercise period [41, 42]; and (2) 10 weeks of metformin treatment increases basal AMPK $\alpha 2$ activity and muscle glycogen levels in humans [7]. It should also be noted that an acute Intralipid infusion, shown here to reduce AMPK $\alpha 2$ activity, also reduces skeletal muscle glycogen synthesis [43]. Our finding that skeletal muscle glycogen synthesis is impaired in $\alpha 2-\mathrm{KD}$ mice demonstrates that AMPK $\alpha 2$ plays a role in this process. However, our findings differ from those of Viollet et al [44], who found impaired muscle glycogen synthesis in $A m p k \alpha 2^{-/-}$mice (global deletion of Ampk $\alpha$ ), but not in $\alpha 2-\mathrm{KD}$ mice (muscle-specific mutation) during an in vivo insulin clamp. The reason for this difference is unclear, especially when considering that basal GS activity in vitro is markedly increased in skeletal muscle of $A m p k \alpha 2^{-/-}$[45], but not in $\alpha 2-\mathrm{KD}$ mice [18].
Fig. 7 Blood glucose (a), GIR

(b), Endo $R_{\mathrm{a}}(\mathbf{c})$ and $R_{\mathrm{d}}(\mathbf{d})$ before (Basal) and in response to an insulin clamp ( 0 to $120 \mathrm{~min}$ ) in wild-type (WT) mice (white circles/bars) and mice producing $\alpha 2-\mathrm{KD}$ in skeletal muscle (black circles/ bars). (e) Glycogen levels following the insulin clamp and (f) glycogen synthesis during the insulin clamp. Data are mean \pm SEM for $n=5-6$; $* p<0.05$ vs corresponding WT value; ${ }^{\dagger} p<0.05$ vs Basal; ${ }^{\star} p=0.05$
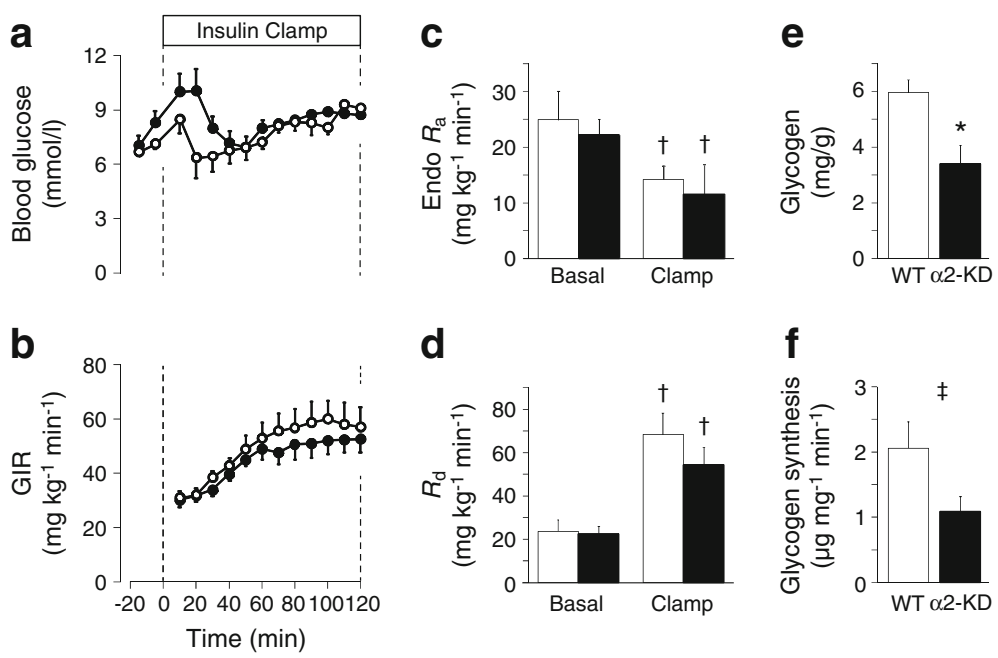
Skeletal muscle iNOS activation is enhanced under conditions of chronic obesity and insulin resistance $[8$, 9], while activation of AMPK $\alpha 2$ via AICAR has been shown to suppress iNOS in rodents and cell culture [12, 13]. In the present study, a short-term elevation of lipid levels was used to create insulin resistance. This was associated with reduced AMPK $\alpha 2$ activity in skeletal muscle and, as seen by others, increased skeletal muscle iNOS levels [46]. Infusion of Intralipid is sufficient to induce inflammatory markers in plasma [10] and skeletal muscle [47] of overnight fasted C57BL/6J mice. Indeed, Tnf $\alpha$ (also known as Tnf) expression increased in skeletal muscle after as little as $30 \mathrm{~min}$ of Intralipid [47]. Acute $(24 \mathrm{~h})$ infusion of $\mathrm{TNF} \alpha$ suppresses AMPK $\alpha$ activity in mouse skeletal muscle [48]. Thus, it is quite possible that induction of TNF $\alpha$ over the $5 \mathrm{~h}$ Intralipid infusion protocol in the present study accounted for the observed suppression of AMPK $\alpha 2$ activity. However, the failure of AICAR-induced activation of $A M P K \alpha 2$ to normalise iNOS abundance or activity in skeletal muscle suggests that reduced AMPK activity is not directly linked to elevated iNOS activity. The dose of AICAR required to suppress iNOS in rodent skeletal muscle (bolus injection of $1,000 \mathrm{mg} / \mathrm{kg}$ [12]) is markedly higher than that used in the present study (constant infusion of $1 \mathrm{mg} \mathrm{kg}^{-1} \mathrm{~min}^{-1}$ ). Thus, as with our finding pertaining to muscle glucose uptake, it is possible that the ability of high-dose AICAR to suppress iNOS expression/activation occurs through a mechanism that is independent of AMPK $\alpha 2$.

In conclusion, the acute induction of insulin resistance in healthy mice via an Intralipid infusion is sufficient to reduce AMPK $\alpha 2$ activity and increase iNOS activation in skeletal muscle in vivo. This impaired AMPK $\alpha 2$ activity does not appear to contribute to the increase in iNOS activation or the impaired rates of insulin-stimulated muscle glucose uptake. However, AMPK $\alpha 2$ activity does appear to play a role in determining the cellular fate of glucose within skeletal muscle. Chronic insulin resistance is associated with reduced muscle AMPK $\alpha 2$ activity $[6,14]$ and impaired glycogen synthesis rates [49]. The findings of the present study suggest a link between defective AMPK $\alpha 2$ activation in skeletal muscle and reduced glycogen synthesis rates.

Acknowledgements We thank E.P. Donahue (Vanderbilt Mouse Metabolic Phenotyping Center Hormone and Analytical Core, Vanderbilt University, Nashville, TN, USA) for performing the HPLC analyses.

Funding This work was supported by National Institutes of Health Grants DK054902 and DK059637 (to D.H. Wasserman). R.S. LeeYoung was supported by a mentor-based fellowship from the American Diabetes Association.
Contribution statement RSLY, JSB, WHM, II, BAB, CMH and LK performed the experimental studies and analyses. RSLY and DHW designed the experimental studies and wrote, reviewed and edited the manuscript. $\mathrm{CMH}$ and $\mathrm{LK}$ reviewed and edited the manuscript and contributed to discussions. JSB, WHM, II and BAB reviewed the manuscript. All authors approved the final version of this manuscript.

Duality of interest The authors declare that there is no duality of interest associated with this manuscript.

\section{References}

1. de Lange P, Moreno M, Silvestri E, Lombardi A, Goglia F, Lanni A (2007) Fuel economy in food-deprived skeletal muscle: signaling pathways and regulatory mechanisms. FASEB J 21:3431-3441

2. Seufert J (2006) A fixed-dose combination of pioglitazone and metformin: a promising alternative in metabolic control. Curr Med Res Opin 22(Suppl 2):S39-S48

3. Hardie DG (2007) AMP-activated/SNF1 protein kinases: conserved guardians of cellular energy. Nat Rev Mol Cell Biol 8:774-785

4. Logie L, Harthill J, Patel K et al (2012) Cellular responses to the metal-binding properties of metformin. Diabetes 61:1423-1433

5. Iglesias MA, Ye JM, Frangioudakis G et al (2002) AICAR administration causes an apparent enhancement of muscle and liver insulin action in insulin-resistant high-fat-fed rats. Diabetes 51:2886-2894

6. Lessard SJ, Chen Z-P, Watt MJ et al (2006) Chronic rosiglitazone treatment restores AMPK $\alpha 2$ activity in insulin-resistant rat skeletal muscle. Am J Physiol 290:E251-E257

7. Musi N, Hirshman MF, Nygren J et al (2002) Metformin increases AMP-activated protein kinase activity in skeletal muscle of subjects with type 2 diabetes. Diabetes 51:2074-2081

8. Perreault M, Marette A (2001) Targeted disruption of inducible nitric oxide synthase protects against obesity-linked insulin resistance in muscle. Nat Med 7:1138-1143

9. Torres SH, de Sanctis JB, de L Briceno M, Hernandez N, Finol HJ (2004) Inflammation and nitric oxide production in skeletal muscle of type 2 diabetic patients. J Endocrinol 181:419-427

10. Cha HN, Song SE, Kim YW, Kim JY, Won KC, Park SY (2011) Lack of inducible nitric oxide synthase prevents lipid-induced skeletal muscle insulin resistance without attenuating cytokine level. J Pharmacol Sci 117:77-86

11. Sugita H, Fujimoto M, Yasukawa $T$ et al (2005) Inducible nitricoxide synthase and NO donor induce insulin receptor substrate-1 degradation in skeletal muscle cells. J Biol Chem 280:1420314211

12. Pilon G, Dallaire P, Marette A (2004) Inhibition of inducible nitricoxide synthase by activators of AMP-activated protein kinase: a new mechanism of action of insulin-sensitizing drugs. J Biol Chem 279:20767-20774

13. Di Marco S, Mazroui R, Dallaire P et al (2005) NF-kappa $\mathrm{B}$-mediated MyoD decay during muscle wasting requires nitric oxide synthase mRNA stabilization, HuR protein, and nitric oxide release. Mol Cell Biol 25:6533-6545

14. Bandyopadhyay GK, Yu JG, Ofrecio J, Olefsky JM (2006) Increased malonyl-CoA levels in muscle from obese and type 2 diabetic subjects lead to decreased fatty acid oxidation and increased lipogenesis; thiazolidinedione treatment reverses these defects. Diabetes 55:2277-2285 
15. Mortensen B, Poulsen P, Wegner L et al (2009) Genetic and metabolic effects on skeletal muscle AMPK in young and older twins. Am J Physiol 297:E956-E964

16. Beck Jørgensen S, O’Neill H, Hewitt K, Kemp B, Steinberg G (2009) Reduced AMP-activated protein kinase activity in mouse skeletal muscle does not exacerbate the development of insulin resistance with obesity. Diabetologia 52:2395-2404

17. Sriwijitkamol A, Coletta DK, Wajcberg E et al (2007) Effect of acute exercise on AMPK signaling in skeletal muscle of subjects with type 2 diabetes: a time-course and dose-response study. Diabetes $56: 836-848$

18. Mu J, Barton ER, Birnbaum MJ (2003) Selective suppression of AMP-activated protein kinase in skeletal muscle: update on 'lazy mice'. Biochem Soc Trans 31:236-241

19. Ayala JE, Bracy DP, McGuinness OP, Wasserman DH (2006) Considerations in the design of hyperinsulinemic-euglycemic clamps in the conscious mouse. Diabetes 55:390-397

20. Lee-Young RS, Griffee SR, Lynes SE et al (2009) Skeletal muscle AMP-activated protein kinase is essential for the metabolic response to exercise in vivo. J Biol Chem 284:23925-23934

21. Morgan CR, Lazarow A (1965) Immunoassay of pancreatic and plasma insulin following alloxan injection of rats. Diabetes 14:669-671

22. Ally A, Park G (1992) Rapid determination of creatine, phosphocreatine, purine bases and nucleotides (ATP, ADP, AMP, GTP, GDP) in heart biopsies by gradient ion-pair reversed-phase liquid chromatography. J Chromatogr 575:19-27

23. Fueger PT, Heikkinen S, Bracy DP et al (2003) Hexokinase II partial knockout impairs exercise-stimulated glucose uptake in oxidative muscles of mice. Am J Physiol 285:E958-E963

24. Chan TM, Exton JH (1976) A rapid method for the determination of glycogen content and radioactivity in small quantities of tissue or isolated hepatocytes. Anal Biochem 71:96-105

25. Golden S, Wals PA, Katz J (1977) An improved procedure for the assay of glycogen synthase and phosphorylase in rat liver homogenates. Anal Biochem 77:436-445

26. Steele R, Wall JS, DeBodo RC, Altszuler N (1956) Measurement of the size and turnover rate of body glucose pool by the isotope dilution method. Am J Physiol 187:15-24

27. Kraegen EW, James DE, Jenkins AB, Chisholm DJ (1985) Doseresponse curves for in vivo insulin sensitivity in individual tissues in rats. Am J Physiol 248:E353-E362

28. Lee-Young RS, Ayala JE, Hunley CF et al (2010) Endothelial nitric oxide synthase is central to skeletal muscle metabolic regulation and enzymatic signaling during exercise in vivo. Am J Physiol 298:R1399-R1408

29. Bergeron R, Previs SF, Cline GW et al (2001) Effect of 5aminoimidazole-4-carboxamide-1- $\beta$-D-ribofuranoside infusion on in vivo glucose and lipid metabolism in lean and obese Zucker rats. Diabetes 50:1076-1082

30. Bergeron R, Russell RR 3rd, Young LH et al (1999) Effect of AMPK activation on muscle glucose metabolism in conscious rats. Am J Physiol 276:E938-E944

31. Boon H, Bosselaar M, Praet SF et al (2008) Intravenous AICAR administration reduces hepatic glucose output and inhibits whole body lipolysis in type 2 diabetic patients. Diabetologia 51:18931900

32. Cuthbertson DJ, Babraj JA, Mustard KJ et al (2007) 5-Aminoimidazole4-carboxamide 1- $\beta$-D-ribofuranoside acutely stimulates skeletal muscle 2-deoxyglucose uptake in healthy men. Diabetes 56:2078-2084
33. Shearer J, Fueger PT, Vorndick B et al (2004) AMP kinase-induced skeletal muscle glucose but not long-chain fatty acid uptake is dependent on nitric oxide. Diabetes 53:1429-1435

34. Stoppani J, Hildebrandt AL, Sakamoto K, Cameron-Smith D, Goodyear LJ, Neufer PD (2002) AMP-activated protein kinase activates transcription of the UCP3 and HKII genes in rat skeletal muscle. Am J Physiol Endocrinol Metab 283:E1239-E1248

35. Olsen GS, Hansen BF (2002) AMP kinase activation ameliorates insulin resistance induced by free fatty acids in rat skeletal muscle. Am J Physiol 283:E965-E970

36. Treebak JT, Birk JB, Hansen BF, Olsen GS, Wojtaszewski JF (2009) A-769662 activates AMPK $\beta 1$-containing complexes but induces glucose uptake through a PI3-kinase-dependent pathway in mouse skeletal muscle. Am J Physiol 297:C1041-C1052

37. Aschenbach WG, Hirshman MF, Fujii N, Sakamoto K, Howlett KF, Goodyear LJ (2002) Effect of AICAR treatment on glycogen metabolism in skeletal muscle. Diabetes 51:567-573

38. Hunter RW, Treebak JT, Wojtaszewski JF, Sakamoto K (2011) Molecular mechanism by which AMP-activated protein kinase activation promotes glycogen accumulation in muscle. Diabetes 60:766-774

39. Toole BJ, Cohen PT (2007) The skeletal muscle-specific glycogentargeted protein phosphatase 1 plays a major role in the regulation of glycogen metabolism by adrenaline in vivo. Cell Signal 19:1044-1055

40. Kim YB, Shulman GI, Kahn BB (2002) Fatty acid infusion selectively impairs insulin action on Akt1 and protein kinase $\mathrm{C}$ lambda / zeta but not on glycogen synthase kinase-3. J Biol Chem 277:32915-32922

41. Barnes BR, Glund S, Long YC, Hjalm G, Andersson L, Zierath JR (2005) 5'-AMP-activated protein kinase regulates skeletal muscle glycogen content and ergogenics. FASEB J 19:773-779

42. Milan D, Jeon JT, Looft C et al (2000) A mutation in PRKAG3 associated with excess glycogen content in pig skeletal muscle. Science 288:1248-1251

43. Hoy AJ, Brandon AE, Turner N et al (2009) Lipid and insulin infusion-induced skeletal muscle insulin resistance is likely due to metabolic feedback and not changes in IRS-1, Akt, or AS160 phosphorylation. Am J Physiol 297:E67-E75

44. Viollet B, Andreelli F, Jorgensen SB et al (2003) The AMPactivated protein kinase $\alpha 2$ catalytic subunit controls whole-body insulin sensitivity. J Clin Invest 111:91-98

45. Jorgensen SB, Nielsen JN, Birk JB et al (2004) The $\alpha 2-5{ }^{\prime}$ AMPactivated protein kinase is a site 2 glycogen synthase kinase in skeletal muscle and is responsive to glucose loading. Diabetes 53:3074-3081

46. Charbonneau A, Marette A (2010) Inducible nitric oxide synthase induction underlies lipid-induced hepatic insulin resistance in mice: potential role of tyrosine nitration of insulin signaling proteins. Diabetes 59:861-871

47. Kim BS, Cha HN, Kim YW, Kim JY, Dan JM, Park SY (2009) Inhibition of lipid infusion-induced skeletal muscle insulin resistance by cotreatment with tempol and glutathione in mice. J Pharmacol Sci 110:370-380

48. Steinberg GR, Michell BJ, van Denderen BJ et al (2006) Tumor necrosis factor $\alpha$-induced skeletal muscle insulin resistance involves suppression of AMP-kinase signaling. Cell Metab 4:465-474

49. Del Prato S, Bonadonna RC, Bonora E et al (1993) Characterization of cellular defects of insulin action in type 2 (non-insulindependent) diabetes mellitus. J Clin Invest 91:484-494 